\title{
Реабілітаційний діагноз у системі фізичної терапії осіб з хронічним обструктивним захворюванням легень
}

\author{
Тимрук-Скоропад К. А. \\ Львівський державний університет фізичної культури, м. Львів, Україна
}

Актуальність. Враховуючи сучасну парадигму охорони здоров'я та фізичної терапії 3 іх фокусуванням на функціонуванні людини, іiї активності й участі (Мельникова Е. В. зі співавт., 2017), реабілітаційний діагноз має базуватися на Міжнародній класифікації функціонування, обмеження життєдіяльності та здоров’я (МКФ).

Реабілітаційний діагноз (РД) - це список проблем пацієнта, сформульований укатегоріях МКФ, що відображає всі актуальні аспекти функціонування пацієнта (Шмонин А. А. зі співавт., 2017). Індивідуалізація реабілітаційного втручання, у тому числі фізичної терапії (ФТ), відбувається вже на етапі встановлення реабілітаційного діагнозу.

Мета дослідження: проаналізувати принципи встановлення реабілітаційного діагнозу в системі фізичної реабілітації пацієнтів з ХОЗЛ.

Результати дослідження та їх обговорення. У РД включають виявлені проблеми пацієнта, які впливають на його функціонування, використовуючи усі категорії МКФ. Встановлення РД відбувається після обстеження пацієнта, зокрема, фізичним терапевтом.

Враховуючи полісистемність ХОЗЛ, існуючі клінічні настанови щодо легеневої реабілітації, сучасні клінічні дослідження, обстеження пацієнтів у процесі ФТ повинне бути всебічним (Тимрук-Скоропад К. А., 2018).
У процесі ФТ пацієнтів з ХОЗЛ слід включати оцінювання наступних аспектів:

1. Якість життя та складові якості життя.

2. Прояв симптомів захворювання.

3. Рухова сфера.

4. Показники дихальної та серцево-судинної систем.

5. Показники госпіталізації.

6. Інтегральні показники.

7. Інформованість, грамотність і освіченість пацієнтів.

На основі обстеження пацієнта фізичний терапевт в межах своєї компетенції складає список проблем, сформульованих у категоріях МКФ, проводить кількісне оцінювання прояву порушення або обмеження та ролі фактора середовища.

На жаль, використання зменшеного списку доменів у вигляді інструменту ICFcore-set (набір базових категорій МКФ) для обструктивних захворювань легень (ОЗЛ) $є$ обмеженим. Тому ICF-core-set для ОЗЛ доцільно брати за основу, пам'ятаючи про можливість використання категорій МКФ, які не потрапили у базовий набір.

Висновки. Індивідуалізація фізичної терапії пацієнтів з ХОЗЛ розпочинається на етапі встановлення реабілітаційного діагнозу.

Ключові слова: реабілітаційний діагноз, фізична терапія, ХОЗЛ. 